\title{
Comparative Study of Antioxidant Activities of Selected Medicinal Plants of Shujabad Area in Multan, Pakistan
}

\author{
Salma Ghaffar, ${ }^{1}$ Shazia Jabeen, ${ }^{2}$ Tahir Mehmood ${ }^{3}$ Muhammad Qasim Hayat, ${ }^{4}$ Mudassir IqbalI ${ }^{5 *}$
}

\section{Salma Ghaffar, ${ }^{1}$ Shazia Jabeen, ${ }^{2}$ Tahir Mehmood, ${ }^{3}$ Muhammad Qasim Hayat, ${ }^{4}$ Mudassir Iqbal ${ }^{5, *}$}

\section{'Department of Botany, The Women University Multan, Multan, PAKISTAN. ${ }^{2}$ Department of Environmental Sciences, The Women University Multan, Multan, PAKISTAN. \\ IInstitute of Biochemistry and Biotechnology, University of Veterinary and Animal Sciences-VVAS, Lahore, PAKISTAN. \\ ${ }^{4}$ Medicinal Plants Research Laboratory, Department of Plant Biotechnology, Atta Ur Rehman School of Applied Biosciences (ASAB), National University of Sciences and Technology (NUST),} Islamabad, PAKISTAN.

${ }^{5}$ Department of Chemistry, School of Natural Sciences, National University of Sciences and Technology (NUST), Islamabad, PAKISTAN.

Correspondence

Dr. Mudassir Iqbal

Department of Chemistry, School of Natural Sciences, National University of Sciences and Technology (NUST), H-1244000 Islamabad, PAKISTAN.

E-mail: mudassir.iqbal@sns.nust.edu.pk

History

- Submission Date: 06-07-2021;

- Review completed: 07-09-2021;

- Accepted Date: 02-12-2021.

DOI : 10.5530/fra.2021.2.11

Article Available online

http://www.antiox.org

\section{Copyright}

(C) 2021 Phcog.Net. This is an openaccess article distributed under the terms of the Creative Commons Attribution 4.0 International license.

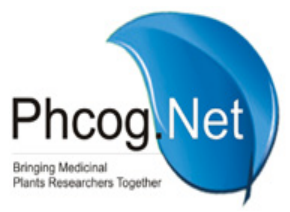

\begin{abstract}
Background: In humans, especially in elderly patients, free radicals and oxidative stress are one of the main reasons behind a number of diseases/disorders, such as cardiovascular, pulmonary and neuronal in nature. Therefore, it is imperative to investigate substances/compounds that possess potent free radical scavenging activity, especially, from the indigenous flora. Methods: The present study was aimed to screen the free radical scavenging activity of ethanolic and methanolic leaf extracts of three medicinal plants: Syzygium cumini, Psidium guajava and Callicarpa dichotoma. The antioxidant activity was determined using 1,1-Diphenyl-2-picryl hydroxyl (DPPH) and Hydrogen peroxide $\left(\mathrm{H}_{2} \mathrm{O}_{2}\right)$ scavenging assays. Various concentrations $(250,500,750$ and $1000 \mu \mathrm{g} / \mathrm{ml})$ of plant extract were used to carry out the assays and Ascorbic acid was used as the standard. The free radical quenching potential was expressed in inhibition percentage (\%) and concentrations were expressed in $\mu \mathrm{g} / \mathrm{ml}$. Optical density of DPPH and $\mathrm{H}_{2} \mathrm{O}_{2}$ was measured using spectrophotometer at 517 and $230 \mathrm{~nm}$, respectively. Results: Results from the DPPH and $\mathrm{H}_{2} \mathrm{O}_{2}$ assays showed that antioxidant activities were observed to be highest in P. guajava ( 89 and $81 \%$ respectively) followed by S. cumini ( 84 and $72 \%$ respectively) and C. dichotoma (83 and $70 \%$ respectively) in the ethanolic extracts. Conclusion: It is concluded that the selected plant materials used for the study have a powerful antioxidant potential and could be used in various therapeutic and medicinal applications.

Key words: ROS, Antioxidant, $C$. dichotoma, P. guajava, S. cumini, DPPH assay, $\mathrm{H}_{2} \mathrm{O}_{2}$ assay.
\end{abstract}

\section{INTRODUCTION}

Medicinal plants are preferred all over the world for treating and preventing numerous diseases because of being rich source of therapeutic agents and thus have occupied a significant place in the sociocultural, spiritual and medicinal field since ancient times. ${ }^{1}$ Globally, a large number of plants (between 21,000 and 70,000) are used for medicinal purposes. ${ }^{2}$ In developing countries, more than $75 \%$ population majorly depends on indigenous plants/herbal plants for maintenance of their health and treatment of various ailments because of their availability, low cost and safety ${ }^{3}$ in comparison to the chemically synthesized drugs that have shown to pose various harmful and toxic effects on humans. ${ }^{4}$

In recent decades, emphasis has been given on developments in medicinal plants and they are natural sources of biologically active compounds. ${ }^{5}$ Plants are considered as major source of bioactive molecules that are used as starting materials in laboratory for the synthesis of drugs and for synthesizing bioactive compounds. Nowadays, these bioactive phytoconstituents have also gained more attention among food industries because of having properties of retarding the lipids degradation, inhibiting microbial damages, and improving the food production. ${ }^{6}$
Antioxidants are compounds that can stop or slow down important process such as oxidations of lipids or other molecules by stopping the initiation of oxidative chain reaction. Thus, it can repair or prevent the damages in the human body cause by oxygen. The antioxidants are functioning in the following manners: Scavenging free radicals, reducing agents, powerful complexes of pro-oxidants metals, chelating metal ions and by quenching of singlet oxygen.? During the last decades, the attempts are made to find out naturally occurring antioxidants in foods and medicinal plants to remove synthetic antioxidants with that of natural ones Different plant extracts containing phytochemicals have been reported to have antioxidant activity and their polyphenolic constituents exhibiting a powerful radical scavengers and stoppage of lipid peroxidation. ${ }^{8}$

This work provides knowledge of selected medicinal plant leaves as potential source of natural antioxidants in future. The interest in use of these traditional uses of medicine has increased all over the world because of no harmful effect. ${ }^{9}$ Most of natural compounds in the plant have been proved as having potent antioxidant activity and also used as free radical or active oxygen and nitrogen scavengers. As natural antioxidants become helpful in retarding the aging

Cite this article: Ghaffar S, Jabeen S, Mehmood T, Hayat MQ, Iqbal M. Comparative Study of Antioxidant Activities of Selected Medicinal Plants of Shujabad Area in Multan, Pakistan. Free Radicals and Antioxidants. 2021;11(2):46-51. 
process in human body and also save human from chronic diseases like cardiovascular disease, cancer, diabetes, arthritis and obesity. ${ }^{10}$

Numerous studies around the world have reported the screening of the antioxidants from; however, there is limited work performed on the leaves of fruits in Pakistan. Thus, the main aims of the study are to screen antioxidant profile in two different extracts (methanolic and ethanolic) of three important medicinal plants: Syzygium cumini (Jamun), Psidium guajava (Guava) and Cordia dichotoma (Lasore) using antioxidant assays like hydrogen peroxide scavenging and 1,1-diphenyl-2-picryl-hydrazyl (DPPH) free radical scavenging; and to explore the relationship between DPPH and hydrogen per oxide scavenging activity.

\section{MATERIALS AND METHODS}

\section{Collection and Identification of Plant Samples:}

Shujabad was selected as study area. The area around the city is fertile. The land of this area has become ideal for agriculture because of very hot weather with average temperature $44^{\circ} \mathrm{C}\left(111^{\circ} \mathrm{F}\right)$ (Figure 1). ${ }^{11}$ Three medicinal plants were selected for the study: Syzygium cumini (SG), Psidium guajava (PG) and Cordia dichotoma (CD). These plants preferred because of their leaves are easily available at every season. The selected plants were further authenticated by Prof Ms. Mussarat Tahir with her experience at the Department of Botany, The Women University, Multan, Pakistan.

\section{Drying and Grinding of Samples}

Leaves $(3000 \mathrm{~g})$ were collected from each plant for the study. The collected leaves were washed thoroughly with tap water to remove dust particles. The leaves were air-dried by using ceiling fan in a room. The sides of the leaves were daily changed from upper to lower and lower to upper side until they dried completely. Dried leaves were grounded into fine powder by using mortar and pestle and liquid nitrogen. They were coarsely powdered into 100 mesh size. The fine leaf powder was packed separately and labeled polythene bags and was stored at $4^{\circ} \mathrm{C}$.

\section{Preparation of Extracts (Serial extraction)}

The air-dried ground plant material from each labeled polythene bags ( $3 \mathrm{~g}$ for each sample) was extracted with chloroform solvent to remove chlorophyll from the leaves. The mixture was soaked for three days and filtered using Whattman filter paper No. 40 and 10 min shaking with orbital shaker. Each filtrate was placed separately on Petri dishes to dry at room temperature and dark. The residue was again extracted with absolute methanol and was filtered after three days by soaking and shaking like above. Then residue was further extracted with deionized distilled water and filtered after three days (Figure 2). ${ }^{12}$ The extract

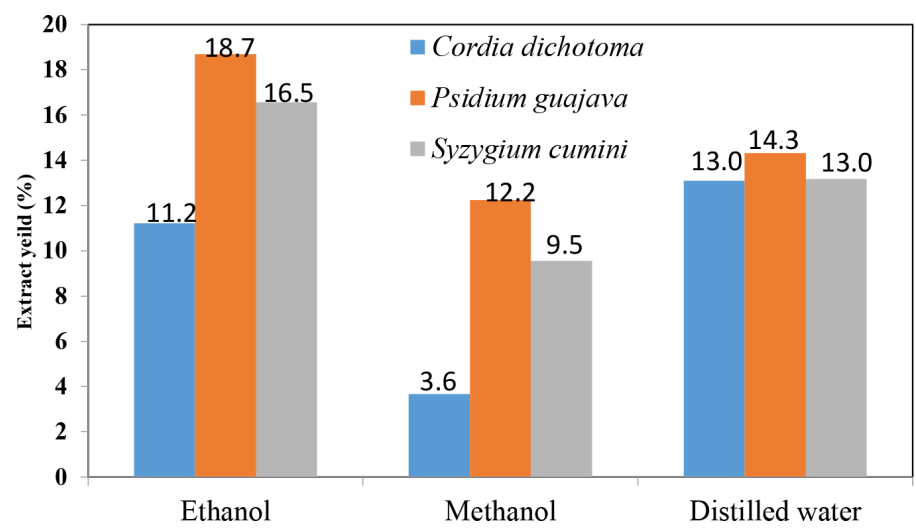

Figure 1: Percentage (\%) yield of plant extracts from different solvent.
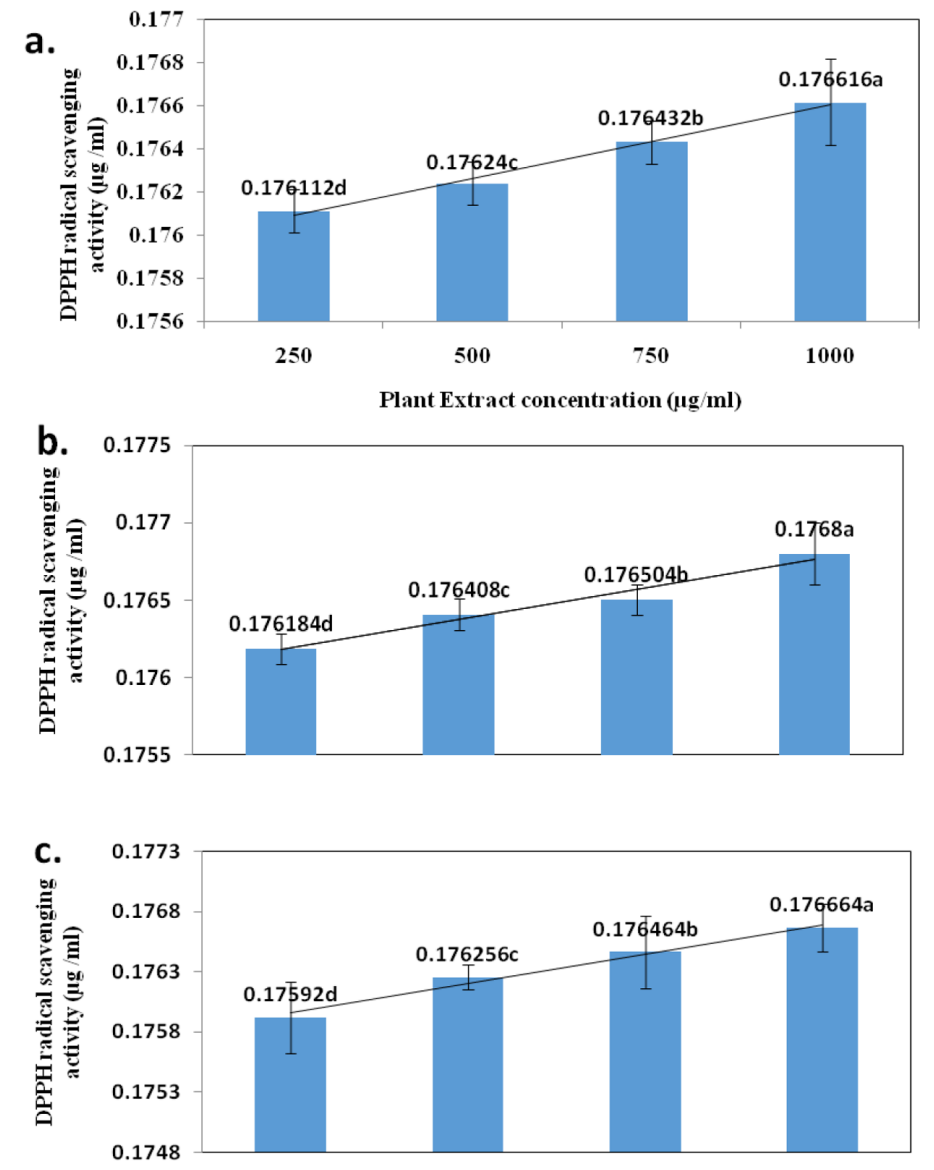

Figure 2: Antioxidant effect by DPPH assay of the methanol extracts of leaves of medicinal plants (a). C. dichotoma (b). P. guajava (c). S. cumini. The values represent means of triplicates. Error bars represent SE $(n=3)$. Different letters above the average bars represent significant differences at ${ }^{*} p<0.05$-Tukey's Test.

obtained from the three solvents i.e. ethanol, methanol and distilled water was preserved at $4^{\circ} \mathrm{C}$ until used for further analyses for antioxidant activity by DPPH and $\mathrm{H}_{2} \mathrm{O}_{2}$ assays. The yield of extract was determined by the following formula:

Amount of extract $(\mathrm{mg})=$ Weight of dry extract with petridish Weight of petridish

$$
\% \text { Extract yield }=\frac{\text { Dry weight of extract }}{\text { Total starting plant material (Residue) }} \times 100
$$

\section{Preparation of Dilutions}

About $100 \mathrm{mg}$ of each medicinal plant leaves extracts was taken and dissolved in methanol and phosphate buffer, respectively and final volume of flask was made to $100 \mathrm{ml}$ with the same respective solvents. The final concentrations of solutions were $1000 \mu \mathrm{g} / \mathrm{ml}$ that was used as stock solutions for making further dilutions. The different concentrations $(250,500,750$ and $1000 \mu \mathrm{g} / \mathrm{ml})$ from stock solutions were prepared by adding methanol and phosphate buffer, respectively. ${ }^{13}$ 


\section{Determination of Antioxidant Activity}

1, 1-diphenyl-2-picrylhydrazyl Radical Scavenging Assay: The stable radical reagent (Sigma Aldrich, WI) DPPH (1,1-diphenyl-2picrylhydrazyl (DPPH Assay) was used to determine the antioxidant capacity of the samples through spectrophotometric analysis. The methodology was adopted from Sadiq et al., $2014^{14}$ with some slight. The following concentrations of the plant extracts were prepared, $0.25,0.5$, 0.75 and $1.0 \mathrm{mg} / \mathrm{ml}$ in methanol and ethanol. About $25 \mu \mathrm{l}$ is added into $975 \mu \mathrm{DPPH}$ solution. The DPPH solution was made by adding $2.5 \mathrm{mg}$ $\mathrm{DPPH}$ in $100 \mathrm{ml}$ of methanol. The mixture was shaken and incubated for $30 \mathrm{~min}$ in the dark at room temperature. A blank solution was made by adding the same amount of methanol and DPPH. The absorbance value of the reaction mixture and standard was recorded at $517 \mathrm{~nm}$ through spectrophotometer (UV-1602). ${ }^{14}$ The percentage of DPPH scavenging activity was calculated by the following equation:

Percentage of DPPH scavenging activity $=\frac{\left(A_{\text {control }}-A_{\text {sample }}\right) \times 100}{}$ A control

Where as

$\mathrm{A}_{\text {control }}=$ Absorbance of control sample

$\mathrm{A}_{\text {sample }}=$ Absorbance of the sample containing plant extract/standard

Calibration curve for Ascorbic acid (Vitamin C) was used as standard at concentrations of 100 to $1000 \mu \mathrm{g} / \mathrm{ml}^{.14}$ The concentration of DPPH $(\mu \mathrm{g} / \mathrm{ml})$ in the assay medium was determined using standard calibration curve having linear regression. (Figure 3 and 4 )

$\mathrm{R}^{2}=0.986$ (Ethanol)

$\mathrm{R}^{2}=0.919$ (Methanol)
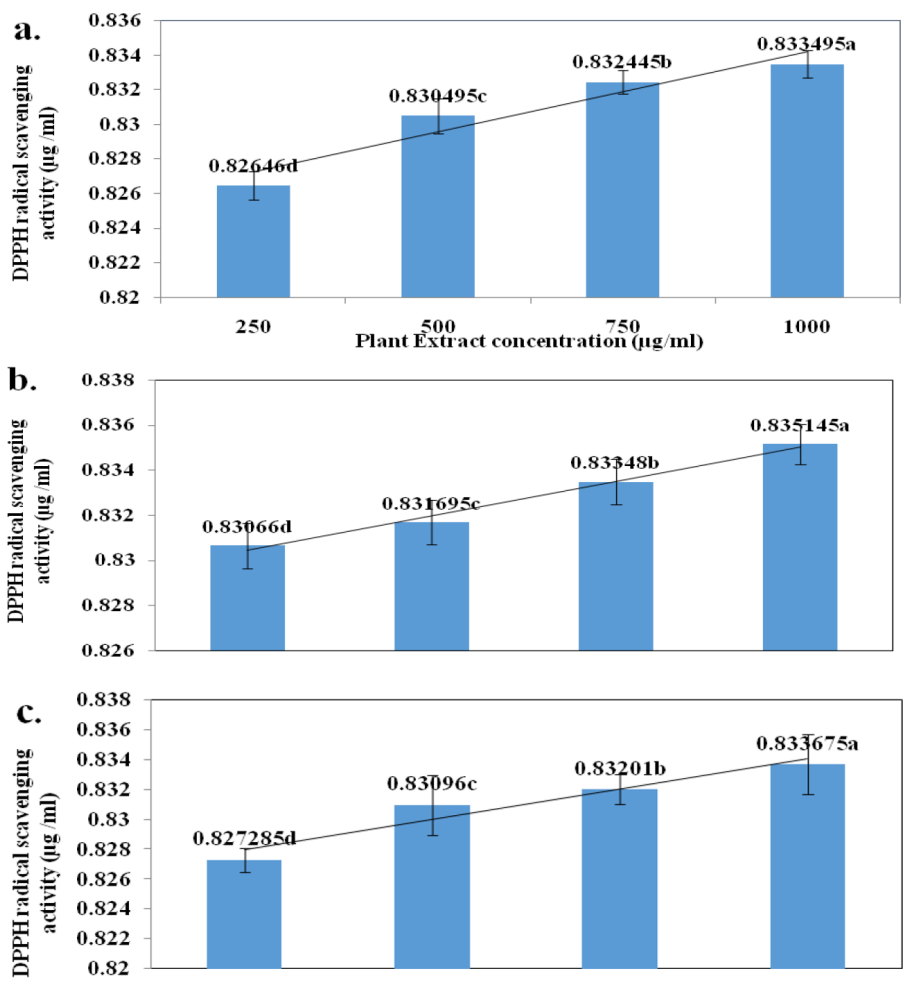

Figure 3: Antioxidant effect by DPPH assay of the ethanolic extracts of leaves of medicinal plants (a). C. dichotoma (b). P. guajava (c). S. cumini. The values represent means of triplicates. Error bars represent SE $(n=3)$. Different letters above the average bars represent significant differences at * $p<0.05$-Tukey's Test.
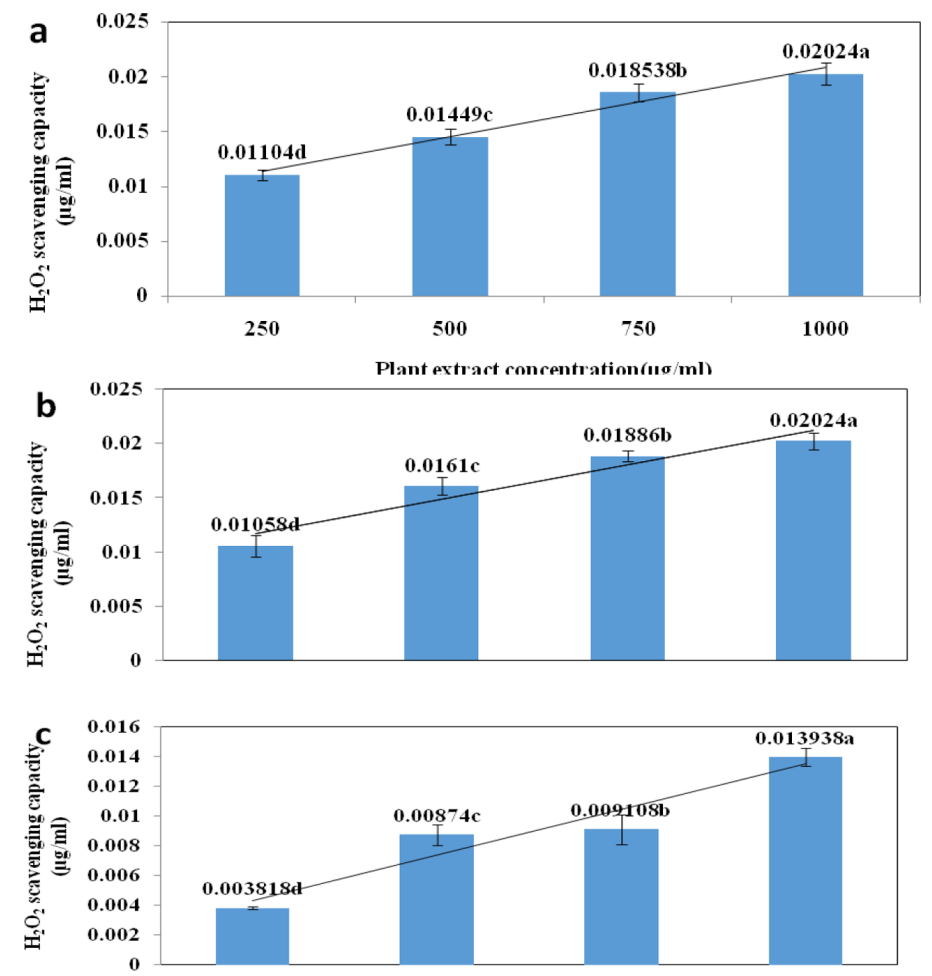

Figure 4: Antioxidant effect by $\mathrm{H}_{2} \mathrm{O}_{2}$ assay of the methanol extracts of leaves of medicinal plants (a). C. dichotoma (b). P. guajava (c). S. cumini. The values represent means of triplicates. Error bars represent SE $(n=3)$. Different letters above the average bars represent significant differences at ${ }^{*} p<0.05$-Tukey's Test.

\section{Hydrogen Peroxide Scavenging Capacity}

The Hydrogen Peroxide $\left(\mathrm{H}_{2} \mathrm{O}_{2}\right)$ scavenging activity was screened by the procedure performed by the Ruch et al., 1989. The $\mathrm{H}_{2} \mathrm{O}_{2}$ Scavenging potential of the plant leaves extract was determined with some modifications as reported. The solution of $\mathrm{H}_{2} \mathrm{O}_{2}$ has been made in PBS (Phosphate Buffer Saline). $4 \mathrm{ml}$ of each extract was taken and $0.6 \mathrm{ml}$ of $4 \mathrm{mM} \mathrm{H}_{2} \mathrm{O}_{2}$ was added and the reaction mixture was incubated in the dark for $10 \mathrm{~min}$. The absorbance of reaction mixture and the standard was recorded at $230 \mathrm{~nm}$ through spectrophotometer (which make and model). The blank solution contained the sodium phosphate buffer without $\mathrm{H}_{2} \mathrm{O}_{2}$ and Ascorbic acid was used as the standard. The \% age of $\mathrm{H}_{2} \mathrm{O}_{2}$ free radical scavenging activity was determined by the following formula.

$$
\text { Percentage of } \mathrm{H}_{2} \mathrm{O}_{2} \text { scavenging activity }=\frac{\left(\mathrm{A}_{\text {control }}-\mathrm{A}_{\text {sample }}\right) \times 10}{\mathrm{~A}_{\text {control }}}
$$

Where as

$\mathrm{A}_{\text {control }}=$ Absorbance of control sample

$\mathrm{A}_{\text {sample }}=$ Absorbance of the sample containing plant extract/standard

By using the standard calibration curve (Figure 5), the concentration of extracts was determined having linear regression. $(R 2=0.977)$.

\section{Statistical Analysis}

The experimental procedures were performed in triplicates. Data were expressed as mean \pm standard error and analyzed by using Statistical Package for Social Science (SPSS) (version 17, for Window10, SPSS Inc). MANOVA (multivariate analysis of variance) was used to analyze the 

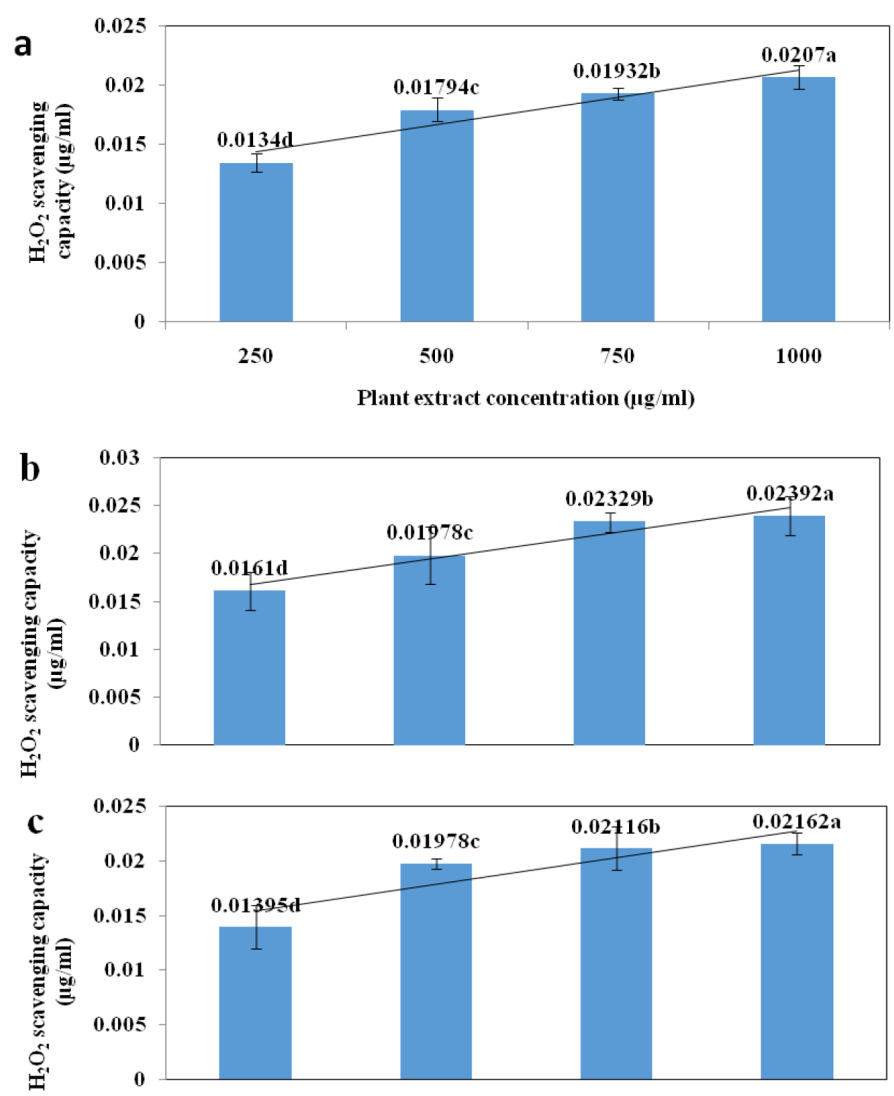

Figure 5: Antioxidant effect by $\mathrm{H}_{2} \mathrm{O}_{2}$ assay of the ethanol extracts of leaves of medicinal plants (a). C. dichotoma (b) P. guajava (c). S. cumini. The values represent means of triplicates. Error bars represent SE $(n=3)$. Different letters above the average bars represent significant differences at * $p<0.05$-Tukey's Test.

statistical significance of the data. The post-hoc Tukey test was used to compare the individual means. The $P$-value i.e. $<0.05$ was preferred for the statistical significance.

\section{RESULTS}

In concern of extracts yield percentage in the serial exhaustive extraction, ethanol extracted highest yield in PG (18.7\%), followed by SC (16.5\%) and then $\mathrm{CD}(11.2 \%)$. In methanol, higher yield was also observed for PG (12.2\%), followed by SC (9.5\%) and then CD (3.6\%). Same in aqueous solvent as PG extracted highest yield (14.3\%), followed by SC (13\%) and then CD (13\%). The highest percentage of the extract yield using ethanolic, methanolic and aqueous extract solvents was observed in PG (18.7 \%, 12.24\% and $14.33 \%$, respectively). Finally, PG extracted highest \% than other plants and on the other hand, distilled water extracted more material from the residue (Figure 1).

In term of antioxidant potential, antioxidant potential of the plant leaves extracted samples were screened through radical scavenging ability using DPPH and $\mathrm{H}_{2} \mathrm{O}_{2}$ assays. The results are represented in Figure 2, $3,4,5$. In the plant material, there present a wide range of variance in antioxidants and their capacity in plant samples. The highest number of total antioxidants was found in PG at all concentration of methanolic extracts $(0.177,0.1765,0.1764$ and $0.1761 \mu \mathrm{g} / \mathrm{ml})$. The highest DPPH scavenging value was shown by PG and followed by CD and then SC. Despite of noticeable implications of the graph, the differences between fractions of methanolic treatment and scavenging effects are significant. Thus, all variables are highly significant $(p<0.05)$.

The results revealed that with increase in concentration of extract the DPPH activity also increased that was also confirmed by the previous literature. ${ }^{15}$ Ethanolic extract of PG demonstrated the highest scavenging properties against DPPH radicals. Our results (Figure 3) showed that in the concentration of $1000 \mu \mathrm{g} / \mathrm{ml}, \mathrm{PG}, \mathrm{CD}$ and SC showed the highest scavenging ability i.e. 72,65 and $67 \%$ in methanolic extract respectively and 89,84 and $84 \%$ in ethanolic extract respectively Table 1.

$\mathrm{H}_{2} \mathrm{O}_{2}$ scavenging capacity in plant ethanolic extracts were tested in three medicinal plants $\mathrm{CD}, \mathrm{PG}$ and SC were assessed for their $\mathrm{H}_{2} \mathrm{O}_{2}$ free radical scavenging activity graphically represented in Figure 4 . The concentration of antioxidant potential by $\mathrm{H}_{2} \mathrm{O}_{2}$ of $\mathrm{PG}$ demonstrated the highest antioxidant activity having $0.024 \mu \mathrm{g} / \mathrm{ml}$ concentrations in 1000 $\mu \mathrm{g} / \mathrm{ml}$ of crude extracts. Secondly PG recognized as possessing powerful antioxidant potential and become strong scavengers of $\mathrm{H}_{2} \mathrm{O}_{2}$. The highest number of total antioxidants was found in PG at all concentration of ethanolic extracts $(0.024,0.023,0.019$ and $0.016 \mu \mathrm{g} / \mathrm{ml})$.

\section{DISCUSSION}

In the present study, a mild technique of extraction i.e., serial extraction was used to extract crude material without any chemical changes. It was selected as a first extraction step in separation of major antioxidant components from the leaves. Since various solvents extract different types of phytochemical constituents. Accordingly, serial extraction used solvents of changeable polarities to enhance the separation of compounds from crude extract. ${ }^{16}$ In this study, we extracted the leaves of three medicinal plants i.e. PG, SC and CD by the serial extraction methods. The best percentage of the ethanolic, methanolic and aqueous yield was observed for PG 18, 12 and $14 \%$ respectively of the total starting weight. Due to the simple and very sensitive method, DPPH method has become more popular in natural antioxidant research literature. ${ }^{17}$

In the present research, methanolic and ethanolic extracts of three selected medicinal plants in four concentrations were screened for their antioxidant potential by DPPH assays. DPPH radical scavenging activity in plant methanolic/ ethanolic extracts in three medicinal plants $\mathrm{CD}, \mathrm{PG}$ and SC were evaluated for their free radical scavenging activity graphically represented in Figures 2 and 3. The scavenging activity increased with increased in concentration of plant extracts.

These findings in Table 1. indicated that PG showed higher antioxidant activity in both ethanolic and methanolic extract. As, it was proved by the previous work, that the guava leaf extracts possess strong antioxidant activity. ${ }^{18}$ Besides the PG other two medicinal plants, CD and SC also showed the appreciable amount of scavenging activity i.e., 65 and $67 \%$ at $1000 \mu \mathrm{g} / \mathrm{ml}$ of methanolic extract and $84 \%$ at $1000 \mu \mathrm{g} / \mathrm{ml}$ of ethanolic extract. Earlier investigations also focused on the antioxidant activity of C. dichotoma and S. cumini) ${ }^{19}$ and also suggested that their leaves have potent antioxidant activity than seeds.

Hydrogen peroxide has powerful oxidizing activity and formed oxidizing enzymes like superoxide dismutase. $\mathrm{H}_{2} \mathrm{O}_{2}$ can easily cross the cell membrane and it can also oxidize many compounds. ${ }^{20}$ There is no literature present that worked on investigating the antioxidant potential by using $\mathrm{H}_{2} \mathrm{O}_{2}$ scavenging assay for the selected medicinal plants used for the study.

Percent scavenging effect of $\mathrm{H}_{2} \mathrm{O}_{2}$ radicals in plant methanolic extracts showed the percentages of $\mathrm{H}_{2} \mathrm{O}_{2}$ scavenging power of three medicinal plants were summarized in Figures 4 and 5. The percentage range of scavenging capacity from $69 \%$ to $13 \%$. The lessening effect of $\mathrm{H}_{2} \mathrm{O}_{2}$ scavenger in medicinal plants was as follow: $\mathrm{PG}>\mathrm{CD}>\mathrm{SC}$. 
Table 1: Comparison of \% DPPH scavenging activity between ethanolic and methanolic leaves extracts.

\begin{tabular}{|c|c|c|c|c|c|c|}
\hline \multirow{2}{*}{$\begin{array}{c}\text { Medicinal plants } \\
\text { Extract } \\
\text { concentration } \\
(\mu \mathrm{g} / \mathrm{ml})\end{array}$} & \multicolumn{2}{|c|}{ C. dichotoma } & \multicolumn{2}{|c|}{ P. guajava } & \multicolumn{2}{|c|}{ S. cumini } \\
\hline & 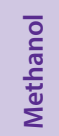 & 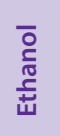 & 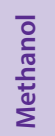 & 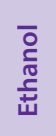 & 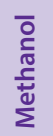 & 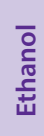 \\
\hline 250 & 45 & 62 & 47 & 75 & 37 & 64 \\
\hline 500 & 50 & 74 & 56 & 78 & 50 & 76 \\
\hline 750 & 57 & 80 & 60 & 84 & 58 & 79 \\
\hline 1000 & 65 & 83 & 72 & 89 & 67 & 84 \\
\hline
\end{tabular}

Table 2: Comparison of $\% \mathrm{H}_{2} \mathrm{O}_{2}$ scavenging activity between ethanolic and methanolic leaves extracts.

\begin{tabular}{|c|c|c|c|c|c|c|}
\hline \multirow{2}{*}{$\begin{array}{l}\text { Medicinal plants } \\
\text { Extract } \\
\text { concentration } \\
(\mu \mathrm{g} / \mathrm{ml})\end{array}$} & \multicolumn{2}{|c|}{$\begin{array}{l}\text { Cordia } \\
\text { dichotoma }\end{array}$} & \multicolumn{2}{|c|}{$\begin{array}{l}\text { Psidium } \\
\text { guajava }\end{array}$} & \multicolumn{2}{|c|}{$\begin{array}{l}\text { Syzygium } \\
\text { cumini }\end{array}$} \\
\hline & 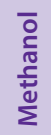 & 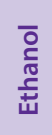 & 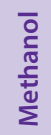 & $\begin{array}{l}\overline{0} \\
\frac{0}{0} \\
\text { D } \\
\text { w }\end{array}$ & 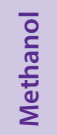 & $\begin{array}{l}\overline{0} \\
\frac{5}{5} \\
\text { 岦 }\end{array}$ \\
\hline 250 & 37 & 45 & 36 & 54 & 13 & 47 \\
\hline 500 & 48 & 60 & 54 & 67 & 29 & 66 \\
\hline 750 & 62 & 65 & 63 & 78 & 30 & 71 \\
\hline 1000 & 69 & 70 & 69 & 81 & 47 & 72 \\
\hline
\end{tabular}

Table 3: Comparison between DPPH and $\mathrm{H}_{2} \mathrm{O}_{2}$ scavenging activity (\%) in methanol and ethanol extract of three medicinal plants.

\begin{tabular}{|c|c|c|c|c|c|c|c|c|c|c|c|c|}
\hline \multirow{3}{*}{$\begin{array}{l}\text { Extract Concentration } \\
\qquad(\mu \mathrm{g} / \mathrm{ml})\end{array}$} & \multicolumn{4}{|c|}{ Codia dichotoma } & \multicolumn{4}{|c|}{ Psidium guajava } & \multicolumn{4}{|c|}{ Syzygium cumini } \\
\hline & \multicolumn{2}{|c|}{ DPPH assay } & \multicolumn{2}{|c|}{$\mathrm{H}_{2} \mathrm{O}_{2}$ assay } & \multicolumn{2}{|c|}{ DPPH assay } & \multicolumn{2}{|c|}{$\mathrm{H}_{2} \mathrm{O}_{2}$ assay } & \multicolumn{2}{|c|}{ DPPH assay } & \multicolumn{2}{|c|}{$\mathrm{H}_{2} \mathrm{O}_{2}$ assay } \\
\hline & $M$ & E & M & $E$ & $M$ & $E$ & $M$ & E & $M$ & $E$ & $M$ & $\mathrm{E}$ \\
\hline 250 & 45 & 62 & 37 & 45 & 47 & 75 & 36 & 54 & 37 & 64 & 13 & 47 \\
\hline 500 & 50 & 74 & 48 & 60 & 56 & 78 & 54 & 67 & 50 & 76 & 29 & 66 \\
\hline 750 & 57 & 80 & 62 & 65 & 60 & 84 & 63 & 78 & 58 & 79 & 30 & 71 \\
\hline 1000 & 65 & 83 & 69 & 70 & 72 & 89 & 69 & 81 & 67 & 84 & 47 & 72 \\
\hline
\end{tabular}

The results of antioxidant properties of methanol and ethanol extracts of the medicinal plants were estimated by DPPH scavenging capacity and $\mathrm{H}_{2} \mathrm{O}_{2}$ scavenging capacity. As from the results discussed above, the antioxidative activities from both methods used in the study (DPPH and $\mathrm{H}_{2} \mathrm{O}_{2}$ ) verified the same sequence of activity. $\mathrm{PG}>\mathrm{CD} \geq \mathrm{SC}$.

In Comparison of $\% \mathrm{H}_{2} \mathrm{O}_{2}$ scavenging activity between ethanolic and methanolic leaves extracts. It is evident from the Table 2 the $\mathrm{H}_{2} \mathrm{O}_{2}$ scavenging ability of plant ethanolic extract was higher than methanolic extract. Analogous to DPPH assay, PG also showed the highest percentage of scavenging activity in all concentrations of ethanolic extract than followed by CD and SC.

Leaf extract of PG have highest scavenging potential at 1000, 750, 500 and $250 \mu \mathrm{g} / \mathrm{ml}$ concentration revealed that guava leaves could be a powerful source of natural antioxidants. Comparison of the outcome of DPPH and $\mathrm{H}_{2} \mathrm{O}_{2}$ assay by both ethanolic and methanolic extract (Table 3) revealed that the ethanolic extract of selected three medicinal plants exhibited the highest antioxidant potential. It was also proved by the previous literature that alcoholic solvents including methanol and ethanol were better than acetone and DMSO. ${ }^{21}$ The highest antioxidant activity in all assays screened in $100 \%$ ethanol extracts. ${ }^{22}$ Two flavonoids, luteolin and apigenin were also found in the ethanolic extract. ${ }^{22}$ Strong antioxidant activity was revealed due to the presence of high quantity of flavonoids. ${ }^{23}$ Therefore, the highest antioxidant activity in medicinal plants is possibly because of presence of flavonoids in ethanol extract.

\section{CONCLUSION}

The three medicinal plants (CD, PG and SC) collected from region of Shujabad, Multan exhibited high level of antioxidant activity. Among these three medicinal plants, PG contained the highest antioxidant potential in both methods used: DPPH and $\mathrm{H}_{2} \mathrm{O}_{2}$. Based on these results, it could be concluded that ethanol extracts of PG can be used as natural antioxidants. Besides PG, CD and SC can also be used as natural antioxidant. These findings also give some directions for therapeutical industry and medicinal fields to utilize these plants derived antioxidants and design powerful and multi target compounds for treating the various chronic diseases related to oxidative stress.

\section{CONFLICT OF INTEREST}

The authors declare no conflict of interest.

\section{REFERENCES}

1. Eddouks M, Ghanimi D. The use of medicinal plants in human healthcare: $A$ scoop on safety. Pharm Regul Aff. 2013;3(1):1-21.

2. Al-Laith AA, Alkhuzai J, Freije A. Assessment of antioxidant activities of three wild medicinal plants from Bahrain. Arab J Chem. 2019;12(8):2365-71. doi: 10.1016/j.arabjc.2015.03.004.

3. Rashid S, Ahmad M, Zafar M, Anwar A, Sultana S, Tabassum S, et al. Ethnopharmacological evaluation and antioxidant activity of some important herbs used in traditional medicines. J Tradit Chin Med. 2016;36(5):689-94. doi: 10.1016/s0254-6272(16)30091-7, PMID 29949320.

4. Haddad M, Zein S, Shahrour H, Hamadeh K, Karaki N, Kanaan H. Antioxidant activity of water-soluble polysaccharide extracted from Eucalyptus cultivated in Lebanon. Asi Paci J. Trop Biomed. 2017;7(10):157-60.

5. Rasool Hassan BA. Medicinal plants (importance and uses). Pharm Anal Acta. 2012;03(10):139-49. doi: 10.4172/2153-2435.1000e139.

6. Dhanani T, Shah S, Gajbhiye NA, Kumar S. Effect of extraction methods on yield, phytochemical constituents and antioxidant activity of Withania somnifera. Arab J Chem. 2017;10:S1193-9. doi: 10.1016/j.arabjc.2013.02.015.

7. Qasim M, Abideen Z, Adnan MY, Gulzar S, Gul B, Rasheed M, et al. Antioxidant properties, phenolic composition, bioactive compounds and nutritive value of medicinal halophytes commonly used as herbal teas. S Afr J Bot. 2017;110:24050. doi: 10.1016/j.sajb.2016.10.005.

8. Singh R, Lawania RD, Mishra A, Gupta R. Role of Cordia dichotoma seeds and leaves extract in degenerative disorders. Inter J Pharma Sci Revie Res. 2010;2(2):21-4.

9. Khan MN, Mobin M, Abbas ZK, ALMutairi KA. Impact of varying elevations on growth and activities of antioxidant enzymes of some medicinal plants of Saudi Arabia. Acta Ecol Sin. 2016;36(3):141-8. doi: 10.1016/j.chnaes.2015.12.009.

10. Gökbulut A, Orhan N, Deliorman Orhan DD. Phenolic compounds characterization, carbohydrate digestive enzyme inhibitory and antioxidant activities of Hieracium pannosum Boiss. S Afr J Bot. 2017;108(3):387-92. doi: 10.1016/j.sajb.2016.08.021.

11. Fikree FF, Mir AM, Haq IU. She may reach a facility but will still die! An analysis of quality of public sector maternal health services, District Multan, Pakistan. J Pak Med Assoc. 2006;56(4):156-63. PMID 16711335. 
12. Das KR. Tiwari Shrivastava V. Techniques for evaluation of medicinal plant products as antimicrobial agents: Current methods and future trends. J Med Plants Res. 2010;4:104-11.

13. Singh R, Lawania RD, Mishra A, Gupta R. Role of Cordia dichotoma seeds and leaves extract in degenerative disorders. Inte $\mathrm{J}$ Phar Sciences Review Res. 2010;2:21-4.

14. Sadiq A. Qualitative and quantitative determination of secondary metabolites and antioxidant potential of Eruca sativa. Nat Prod Chem Res 2014. 2014;2(4):4-14. doi: 10.4172/2329-6836.1000137.

15. Saha MR, Alam A, Hasan R, Akter R, Hossain M, Mazumder EH, et al. In vitro anti-oxidant activity of the leaves of Dillenia indica. Oriental Pharmacy and Experimental Medicine. 2009;9(4):277-84. doi: 10.3742/OPEM.2009.9.4.277.

16. Green RJ. Antioxidant activity of peanut plant tissues. NC State Unv Lib. 2004.

17. Moon JK, Shibamoto T. Antioxidant assays for plant and food components. J Agric Food Chem. 2009;57(5):1655-66. doi: 10.1021/jf803537k, PMID 19182948.
18. Chen HY, Yen GC. Antioxidant activity and free radical-scavenging capacity of extracts from guava (Psidium guajava L.) leaves. Food Chem. 2007;101 (2):686-94 doi: 10.1016/j.foodchem.2006.02.047.

19. Afify AE, SA MM, Fayed EA. Shalaby and El-Shemy HA. Syzygium cumini (pomposia) active principles exhibit potent anticancer and antioxidant activities. Afr J Pharm Pharmacol. 2011;5:948-56.

20. Gülçin I, Huyut Z, Elmastas M, Aboul-Enein HY. Radical scavenging and antioxidant activity of tannic acid. Arab J Chem. 2010;3(1):43-53. doi: 10.1016/j. arabjc.2009.12.008.

21. Sartory DP, Grobbelaar JU. Extraction of chlorophyll a from freshwater phytoplankton for spectrophotometric analysis. Hydrobiologia. 1984;114(3):177-87. doi: 10.1007/BF00031869

22. Hiremath S, Swamy HS, Badami S, Meena S. Antibacterial and antifungal activities of Striga densiflora and Striga orobanchioides. Ind J Pharm Sci. 1996;58:174-84

23. Raj K, Shalini K. Flavonoids-a review of biological activities. Indian Drugs. 1999;36(2):668-76.

Cite this article: Ghaffar S, Jabeen S, Mehmood T, Hayat MQ, lqbal M. Comparative Study of Antioxidant Activities of Selected Medicinal Plants of Shujabad Area in Multan, Pakistan. Free Radicals and Antioxidants. 2021;11(2):46-51. 